\title{
Geologic controls on the recent evolution of oyster reefs in Apalachicola Bay and St. George Sound, Florida
}

\author{
D. Twichell a, ${ }^{\text {a }}$, L. Edmiston ${ }^{\text {b }}$, B. Andrews ${ }^{\text {a }}$, W. Stevenson ${ }^{\text {c }}$, J. Donoghue ${ }^{\mathrm{d}}$, R. Poore ${ }^{\mathrm{e}}$, L. Osterman ${ }^{\mathrm{e}}$ \\ ${ }^{a}$ U.S. Geological Survey, 384 Woods Hole Road, Woods Hole, MA 02543, United States \\ ${ }^{\mathrm{b}}$ Apalachicola Bay National Estuarine Research Reserve, Apalachicola, FL, United States \\ ${ }^{\mathrm{c}}$ NOAA Coastal Services Center, Charleston, SC, Unted States \\ ${ }^{\mathrm{d}}$ Department of Geological Sciences, Florida State University, Tallahassee, FL, United States \\ ${ }^{\mathrm{e}}$ U.S. Geological Survey, St. Petersburg, FL, United States
}

\section{A R T I C L E I N F O}

\section{Article history:}

Received 4 December 2009

Accepted 21 April 2010

Available online 10 May 2010

\section{Keywords:}

oyster reefs

substrate preferences

brackish water environment

Holocene

USA

Florida

Apalachicola Bay

\begin{abstract}
A B S T R A C T
Apalachicola Bay and St. George Sound contain the largest oyster fishery in Florida, and the growth and distribution of the numerous oyster reefs here are the combined product of modern estuarine conditions in the bay and its late Holocene evolution. Sidescan-sonar imagery, bathymetry, high-resolution seismic profiles, and sediment cores show that oyster beds occupy the crests of a series of shoals that range from 1 to $7 \mathrm{~km}$ in length, trend roughly north-south perpendicular to the long axes of the bay and sound, and are asymmetrical with steeper sides facing to the west. Surface sediment samples show that the oyster beds consist of shelly sand, while much of the remainder of the bay floor is covered by mud delivered by the Apalachicola River. The present oyster reefs rest on sandy delta systems that advanced southward across the region between 6400 and $4400 \mathrm{yr}$ BP when sea level was 4-6 m lower than present. Oysters started to colonize the region around $5100 \mathrm{yr}$ BP and became extensive by 1200 and $2400 \mathrm{yr}$ BP. Since $1200 \mathrm{yr}$ BP, their aerial extent has decreased due to burial of the edges of the reefs by the prodelta mud that continues to be supplied by the Apalachicola River. Oyster reefs that are still active are narrower than the original beds, have grown vertically, and become asymmetrical in cross-section. Their internal bedding indicates they have migrated westward, suggesting a net westerly transport of sediment in the bay.
\end{abstract}

Published by Elsevier Ltd.

\section{Introduction}

The Apalachicola Bay estuary contains numerous oyster beds that support the largest oyster fishery in Florida (Whitfield and Beaumariage, 1977). The region lies in the northern Gulf of Mexico along the Florida panhandle at the mouth of the Apalachicola River; the largest river in Florida (Leitman et al., 1983, Fig. 1). This river is the primary supply of fresh water, nutrients, and suspended sediment to the bay (Livingston et al., 2000; Surratt et al., 2008). The full extent of the bay is divided into four sections: St. George Sound, Apalachicola Bay, East Bay, and St. Vincent Sound (Fig. 1). The study area is limited to the Apalachicola Bay and the St. George Sound parts of the estuary where most of the oyster beds occur. The entire estuary is elongate, shallow, and separated from the Gulf of Mexico by four barrier islands (St Vincent, Little St. George, St. George, and Dog) that are separated from

\footnotetext{
* Corresponding author

E-mail address: dtwichell@usgs.gov (D. Twichell).
}

each other by 3 natural passes (Indian Pass, West Pass, and East Pass) and one man-made pass (Sikes Cut). The barrier islands restrict water exchange between the river and the Gulf of Mexico creating estuarine conditions with salinities that vary seasonally, but are usually less than 25 ppt (Niu et al., 1998; Livingston et al., 2000). Circulation within the study area is strongly controlled by river discharge, wind, and to a lesser extent tides (Niu et al., 1998; Livingston et al., 2000; Huang et al., 2002a,b). Land use changes and the construction of dams within the drainage basin has altered the discharge volume and nutrient and suspended sediment levels supplied to the bay (Livingston et al., 2000). Analysis of bay floor sediment records a decrease in nutrient levels in the bay during historic time as well as an increase in salinity attributed to decreased river discharge and the continued rise of sea level (Surratt et al., 2008). Currents flow predominantly parallel to the long axis of the bay and sound with the northeast and southwestdirected currents reaching speeds of $20-30 \mathrm{~cm} / \mathrm{sec}$ (Huang et al., 2002b).

The distribution of the eastern oyster (Crassostrea virginica) is controlled by a variety of environmental factors including salinity, 


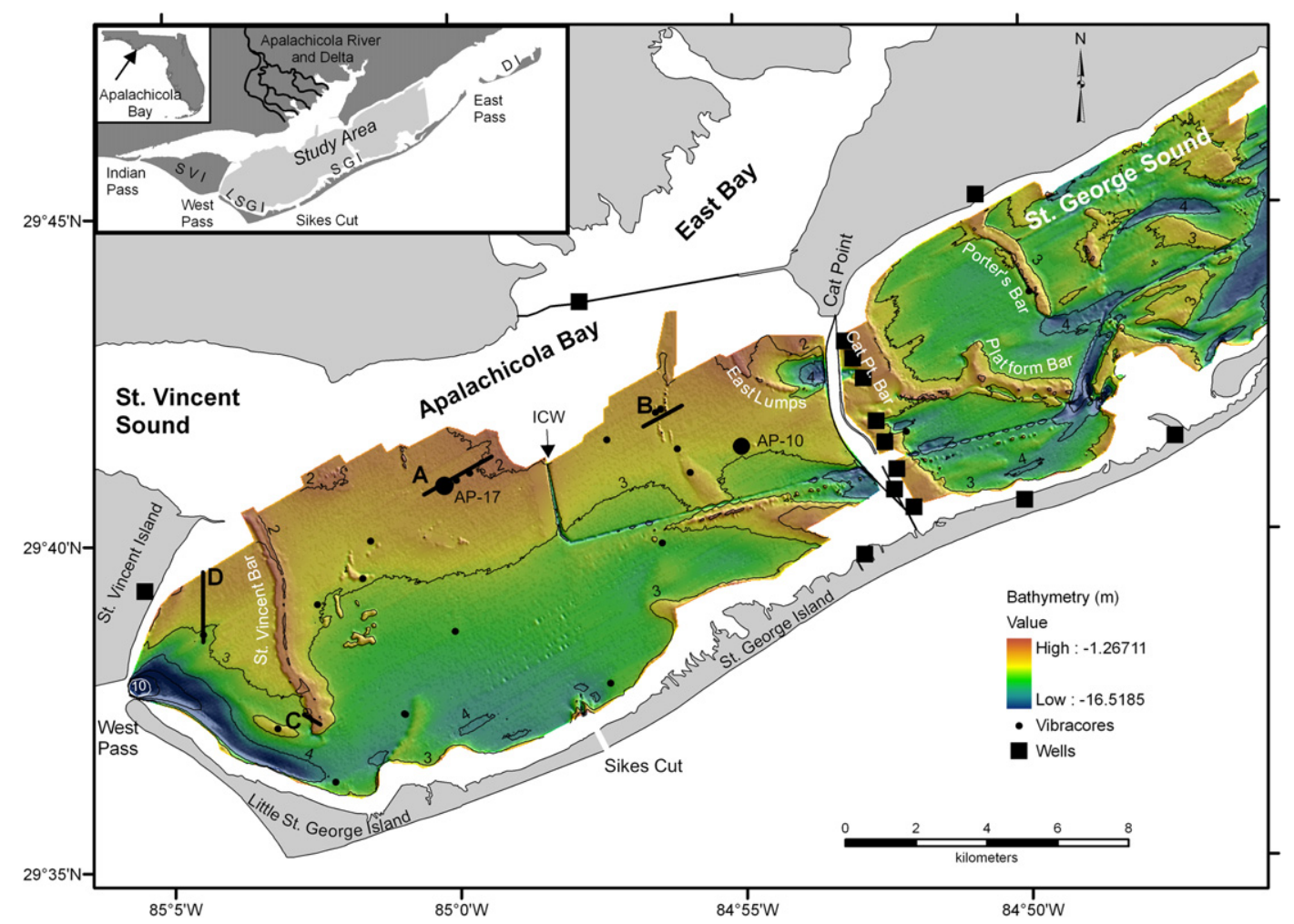

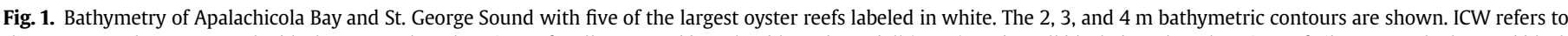

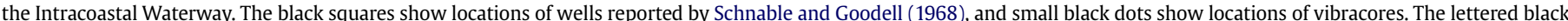

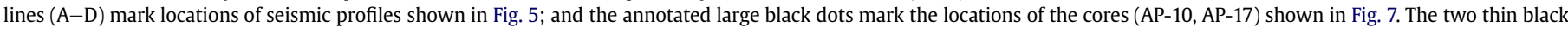
lines connecting Cat Point to St. George Island are the old and new bridges to the island.

temperature, nutrient availability, suspended sediment concentrations, and substrate type (Kennedy et al., 1996; Livingston et al., 2000). Oysters are suspension feeders and tend to occur in dense beds where environmental conditions are appropriate. These beds grow by larvae attaching themselves to hard substrates and, with time, the beds can grow vertically by larvae attaching themselves to other oysters. The vertical growth of oyster beds is advantageous because it allows the living oysters to remain above accumulating fine-grained sediment where nutrient supply is optimal (Lenihan, 1999; Schulte et al., 2009). The importance of geological substrates in controlling oyster bed distribution has become apparent as a result of detailed geophysical surveys. For example, in Chesapeake Bay and the Hudson River (both U.S. Atlantic coast), and Naples Bay (U.S. Gulf of Mexico coast) seismic profiles have shown that oyster beds commonly grow on terraces along the margins of valleys incised during the last lowstand of sea level (DeAlteris, 1988; Smith et al., 2003; Carbotte et al., 2004; Fielder et al., 2006). The substrate underlying the oyster beds in those estuaries is composed of Tertiary and Pleistocene sands while oysters are absent in areas where muddy sediment is dominant.

Previous geologic studies within and around Apalachicola Bay have focused on reconnaissance mapping of the sea floor geology and shallow stratigraphy based on widely spaced sediment samples, seismic profiles, and drilled wells within and around the region (Kofoed and Gorsline, 1963; Schnable and Goodell, 1968; Isphording, 1986; Donoghue, 1992, 1993; Donoghue and White, 1995). Although these geologic data provide a regional understanding of the Pleistocene and Holocene stratigraphy of the area, coverage was insufficient to establish whether there is a relation between modern oyster bed distribution and underlying stratigraphy as has been observed in other estuaries (DeAlteris, 1988;
Smith et al., 2003; Carbotte et al., 2004; Fielder et al., 2006). A recent detailed geophysical survey of a large part of the Apalachicola Bay and the St. George Sound parts of the estuary (Twichell et al., 2007) and a suite of vibracores (Osterman et al., 2009) provide data sets that are adequate to assess the influence of the shallow geologic structures on the distribution of oyster beds.

Biological, chemical and physical processes clearly contribute to the health of oysters within this bay (Livingston et al., 2000) but here we demonstrate how the late Holocene evolution of the bay has also contributed to the spatial distribution of oyster reefs. We use bathymetric, seismic-reflection, core data, and radiocarbon dating to demonstrate the control of the underlying geology on oyster reef distribution, to refine the timing of when oysters colonized the bay floor, and to show how the morphology of the oyster reefs has evolved since initial colonization.

\section{Methods}

Bathymetric data, sidescan-sonar imagery, and high-resolution seismic profiles were collected simultaneously from a large part of Apalachicola Bay and St. George Sound along approximately 2400 $\mathrm{km}$ of northeast-trending lines that were spaced less than $125 \mathrm{~m}$ apart (Twichell et al., 2007). Navigation for these data sets was recorded using a Real Time Kinematic Global Positioning System. Much of the data were collected from the 7.7-m long R/V Rafael during 2005 and 2006, and the remainder was collected in key very shallow areas by means of an autonomous surface vehicle (ASV) (Bergeron et al., 2007). Bathymetric data were collected aboard the R/V Rafael by means of a SEA Submetrix 2000 Series interferometric sonar, operating at a frequency of $234 \mathrm{kHz}$, and single-beam bathymetry was collected from the ASV. Nearly 
continuous $100-\mathrm{kHz}$ sidescan-sonar imagery collected from both vehicles was used to construct a sidescan mosaic of the study area. Subbottom profiles were collected using Edgetech FSSB 424 $(4-24 \mathrm{kHz})$ systems. Full details of the acquisition and processing procedures are given in Twichell et al. (2007).

Vibracores were collected at 24 stations in 2007 from the R/V Gilbert using a Rossfelder electric vibracorer equipped with $6.1-\mathrm{m}$ long aluminum barrels. Cores were split longitudinally, described visually, and selected cores were sampled for textural analysis and radiocarbon dating. A description of the core collection, processing, and cataloging are summarized by Twichell et al. (2009). Faunal analysis and Accelerator Mass Spectrometer (AMS) ${ }^{14} \mathrm{C}$ dating of the cores and a reconstruction of the Holocene depositional environments in the region are presented by Osterman et al. (2009).

\section{Results}

\subsection{Morphology and geology of the bay floor}

Much of Apalachicola Bay has a smooth floor that is $2-2.6 \mathrm{~m}$ deep along the northern margin of the survey area and increases to 3.5-4 m near its southern margin (Fig. 1). Much of St. George Sound lies in the 3.5-4 m depth range. The bay and the sound exceed $5 \mathrm{~m}$ depth in localized depressions where depths can reach $16 \mathrm{~m}$. The largest of these depressions, where depths are greatest, extends east from West Pass along the back of Little St. George Island. The other depressions are at the eastern end of the study area and have maximum depths that reach 4-8 $\mathrm{m}$. A man-made depression is the dredged channel of the Intracoastal Waterway (ICW), which runs through St. George Sound and the eastern part of Apalachicola Bay.

Shoal areas interrupt the smooth sea floor and are long and linear or subcircular in outline (Fig. 1 ). The linear shoals reach $7 \mathrm{~km}$ in length, are less than $1 \mathrm{~km}$ in width, rise $2-3 \mathrm{~m}$ above the surrounding sea floor, and trend roughly perpendicular to the long axis of the study area. St. Vincent Bar is the largest of these shoals, and is found near the western end of Apalachicola Bay. Other large shoals include Cat Point, Platform, and Porter's Bars which are all located east of Cat Point in St. George Sound. Profiles across these shoals show that they are asymmetrical with their steeper side facing towards the southwest (Fig. 2, profiles B, C, D). The subcircular shoals are mostly less than $1 \mathrm{~km}$ in length, rise $1-2 \mathrm{~m}$ above the surrounding sea floor, and are also asymmetrical with their steep sides facing towards the west. These shoals are mostly clustered in two groups in the central part of Apalachicola Bay between St. Vincent Bar and East Lumps (Fig. 2). The linear string of circular mounds along the southern edge of the ICW is dredge spoil.

East of Porter's Bar the sea floor morphology is more irregular than to the west. Several broad troughs that trend roughly east-west occupy this area (Fig. 1). Surrounding these troughs are several small ridges and mounds that decrease in size towards the east. Sand waves are present at the easternmost edge of the study, some with as much as $1-\mathrm{m}$ relief. They are asymmetrical with the steeper sides, like the larger shoals, facing towards the west (Fig. 2, profile A).

The surficial geology of the region was mapped using sidescansonar imagery in concert with sediment grab samples and video observations (Fig. 3). Mud is the dominant sediment type supplied by the Apalachicola River. Mud covers the central area between Porter's and St. Vincent Bars (Figs. 1, 3) except for the shoals themselves and the sea floor immediately surrounding them. West of St. Vincent Bar, east of Porter's Bar, and along the landward margin of the barrier islands, the sea floor is primarily sand or shelly sand.

Oyster beds are represented by moderate to high-backscatter regions on the sidescan-sonar imagery, and they all coincide with the shoals identified in the bathymetry. Stenzel (1971) identified three types of oyster reefs (fringe, string, patch) based on the morphology of reefs in bays along the Texas and Louisiana coasts. Fringe reefs are found adjacent to shore; string reefs are long, narrow ridges that commonly are connected to the shore at one end and trend perpendicular to currents, and patch reefs have irregular shapes, but are small and isolated from the coast. All three oyster reef types are found in the study area. String reefs (Fig. 3) represent the largest area occupied by oysters, and they are concentrated near the western end of Apalachicola Bay (St. Vincent Bar) and adjacent to and east of Cat Point (East Lumps, Cat Point, Platform, and Porter's Bars). Patch reefs are found in the central part of the bay between St. Vincent Bar and East Lumps (Figs. 2, 3). Fringe reefs were not found within our survey, but some extend into Apalachicola Bay from St. George Island (Livingston et al., 2000). Oysters were found only on the shoals, and the only shoals not colonized by oysters lie east of Porter's Bar, west of St. Vincent Bar, and extend into the bay from St. George and Little St. George Islands (Figs. 1, 2).

\subsection{Shallow stratigraphy and Holocene evolution}

Seismic profiles and vibracores collected in the study area and well borings surrounding the study area have been used to reconstruct the shallow stratigraphy beneath Apalachicola Bay and St. George Sound. A large valley that was cut during the last lowstand of sea level extends southward from the present Apalachicola River delta (Schnable and Goodell, 1968; Banister, 2008; Osterman et al., 2009) and connects with a lowstand valley that lies beneath the present barrier island and inner shelf (Donoghue, 1993; McKeown et al., 2004). The seismic data show the confluence of several tributaries with the main valley under the central part of Apalachicola Bay (Fig. 4A). The thalweg of this valley is $22 \mathrm{~m}$ below sea level at a well north of the study area (Schnable and Goodell, 1968) and increases to $25 \mathrm{~m}$ under the inner shelf south of St. George Island. To either side of this valley, the lowstand surface rises to 5-10 m below present sea level and shoals to 3-5 m east of Porter's Bar where it crops out on the sea floor (Fig. 4B).

During the Holocene, the valley was filled with bay-head delta and fine-grained estuarine deposits while the land to either side of the valley initially was eroded by coastal processes as the shoreline transgressed across it (Schnable and Goodell, 1968). Once flooded, fine-grained estuarine and prodelta mud deposits formed a thin blanket over much of the present extent of the study area (Fig. 4B). The accumulation of fine-grained estuarine sediment was not laterally continuous once the bay was flooded however. Seismic profiles show that this acoustically transparent estuarine unit is interrupted in places by a high amplitude reflector (Fig. 5A, B). The distribution of this reflector is shown in Fig. 4A. Vibracores that penetrated it recovered either a 1-2 $\mathrm{m}$ thick sand bed or a sand bed capped with oyster shells in a sandy matrix (Fig. 6). The sand beds rest either directly on the Pleistocene lowstand surface or on top of estuarine mud (Fig. 4B). One seismic profile west of St. Vincent Bar shows that the sandy bed is composed of southward dipping reflections (Fig. 5D). Large parts of these sand beds have subsequently been buried by mud as well (Osterman et al., 2009, Fig. 4B; $5 A, B ; 6)$. The spatial extent of these late Holocene sand sheets (Fig. 4A), the presence of southward-dipping reflections within this interval (Fig. 5D), and the absence of foraminifera in these sandy deposits suggest that they represent deltas that advanced into the bay between 6400 and $4400 \mathrm{yr}$ BP (Osterman et al., 2009). Following the advance of the sandy deltas, sea level rose (Balsillie and Donoghue, 2004), the deltas moved shoreward, and sedimentation returned to the accumulation of prodelta mud along with the growth of oyster reefs. The modern Apalachicola Delta (see 


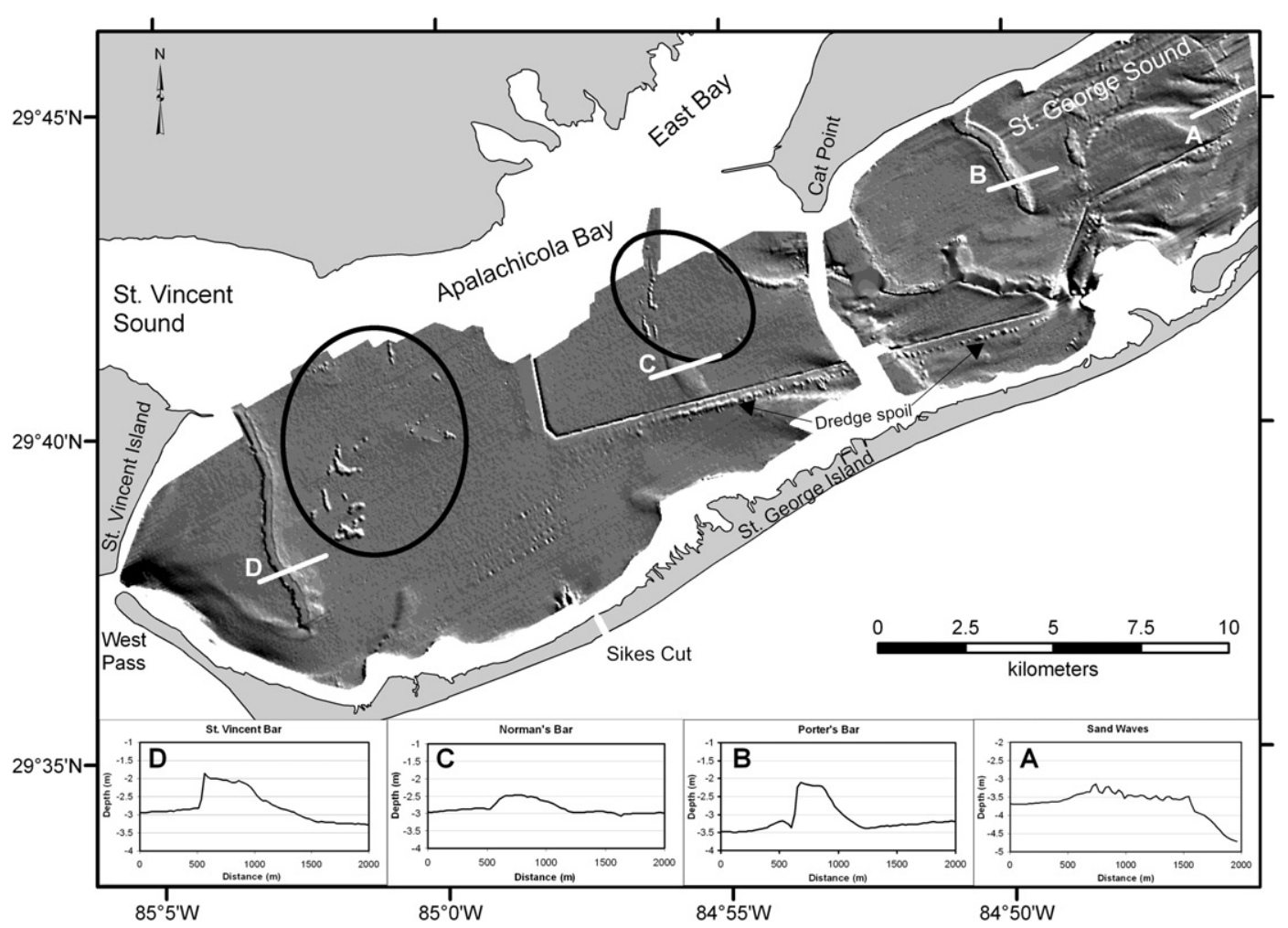

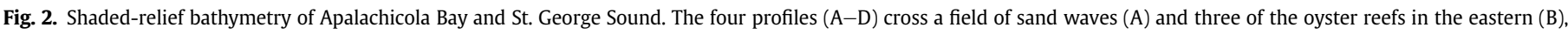

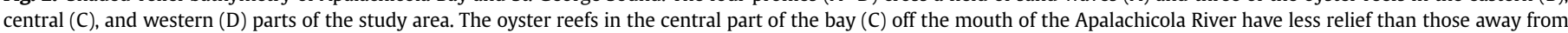
the river mouth. The two black ovals outline the areas where the subcircular patch reefs occur. Vertical exaggeration of profiles A-D is approximately $300: 1$.

inset map of Fig. 1) has formed after the last major rise in sea level. Donoghue and White (1995) reported that virtually all ages obtained from early human sites in the modern delta are $4000 \mathrm{yr}$ BP or younger. Presently, mud supplied by the Apalachicola River continues to accumulate in the central part of the study area but not east of Porter's Bar where Pleistocene sand is exposed on the bay floor or west of St. Vincent Bar where late Holocene sandy delta deposits remain exposed on the bay floor (Figs. 3, 4B).

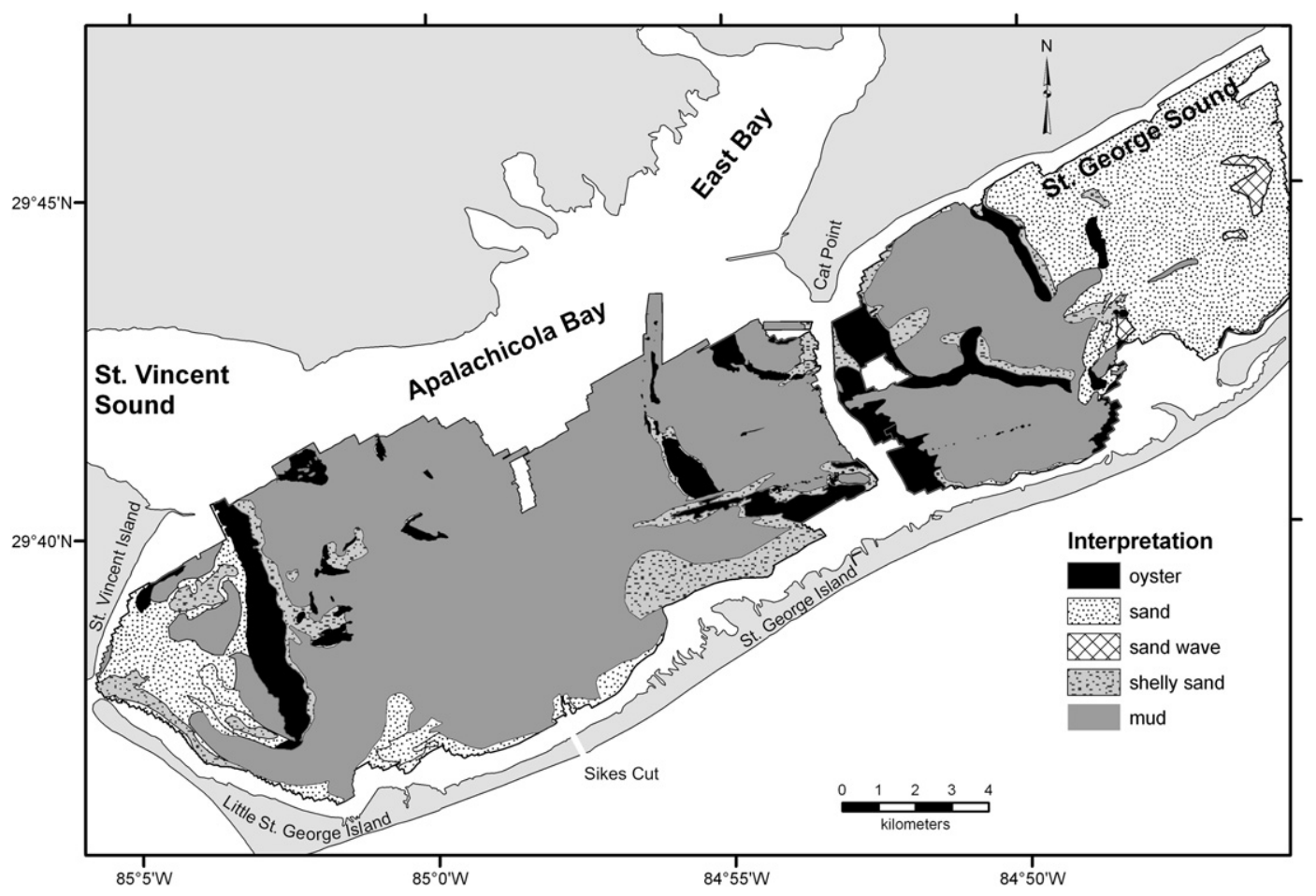

Fig. 3. Surficial geology of the study area in Apalachicola Bay and St. George Sound. 

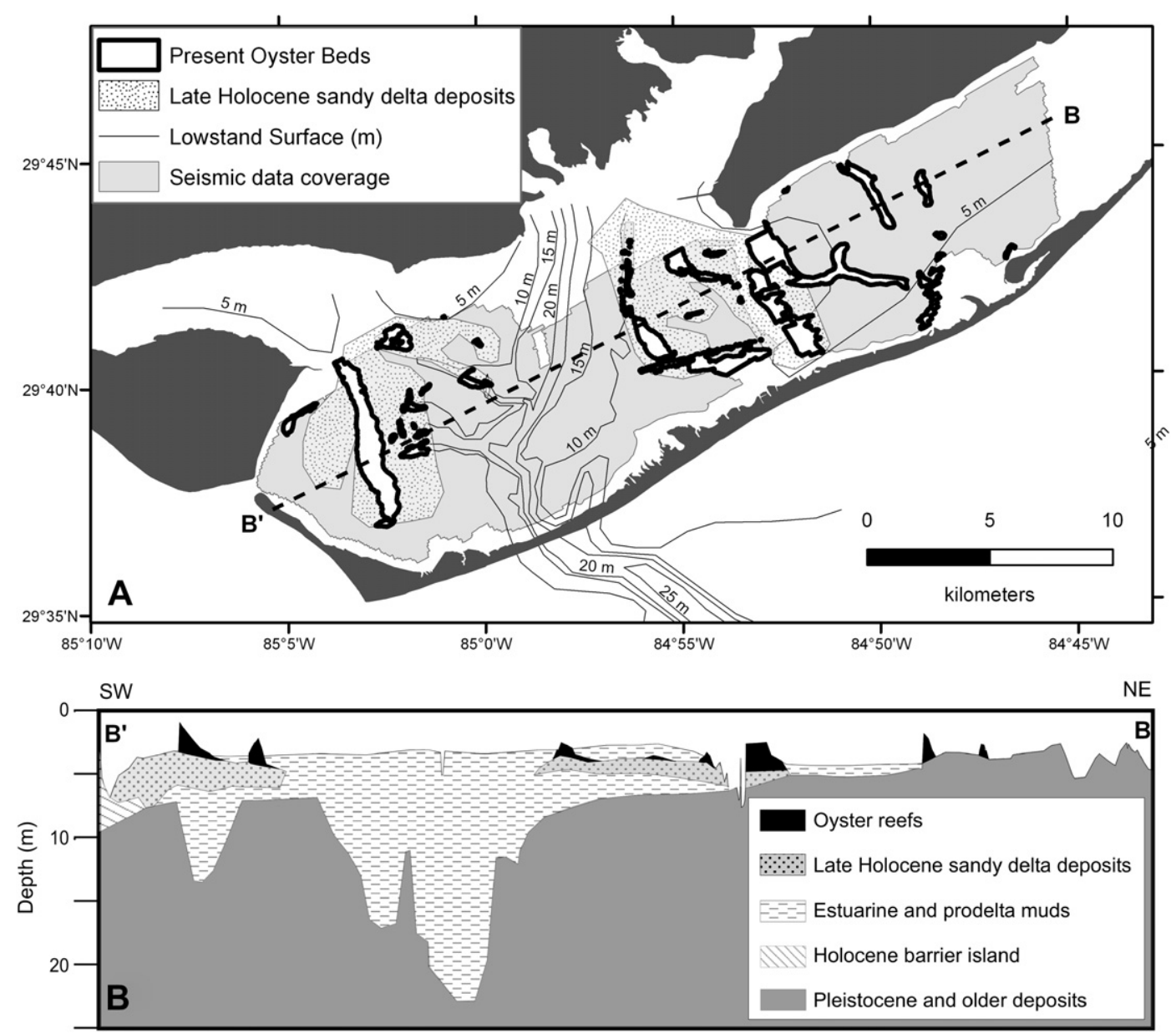

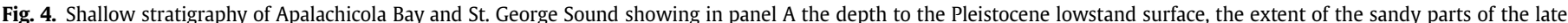

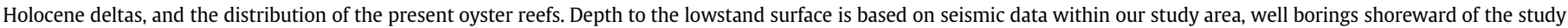

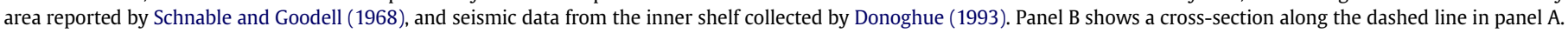
Vertical exaggeration is approximately 400:1.

\subsection{Structure of oyster reefs}

The high-resolution bathymetry, seismic profiles, and vibracores provide further insights into the structure of the oyster reefs themselves. The present oyster beds rest atop Pleistocene sand in St. George Sound and atop Holocene sandy delta deposits in the central and western part of Apalachicola Bay (Fig. 4). In Apalachicola Bay, the vibracores that penetrated the high-amplitude reflector seen on seismic profiles commonly penetrated a layer of oyster shells before entering deltaic sand suggesting that the oyster beds once were more extensive than they are now (Fig. 6). Initially, oysters may have colonized nearly the entire surface of the sandy delta deposits (Fig. 4A), and since have decreased in extent due to burial by prodelta mud.

Bathymetry shows that the exposed parts of the oyster reefs are asymmetrical with their steeper sides facing to the west (Fig. 2 B, C, D). Seismic profiles show that the buried parts of the reefs commonly shoal towards the west (Fig. 5A, 6). The internal structure of the oyster reefs was only resolved seismically for St. Vincent Bar. Several of the profiles collected over the shallow crest of this reef with the ASV show westward dipping reflections with dips that mimic the present slope of the steeper western side of the bar (Fig. 5C).

Cores show that the reefs consist of oyster shells in a matrix of muddy sand. The sand content of the underlying deltaic deposits in the eastern and western parts of Apalachicola Bay ranges from 58 to
$87 \%$ with mean grain sizes between 2.2 and 4.6 phi (Fig. 7). Sand content in the deltas and oyster reefs (Fig. 7) from the eastern part of the bay is higher (70-87\%) than those to the west (58\%); and the mean grain size of the beds in the eastern part of the bay is coarser (2.2-4.1 phi) than those to the west (4.5-4.6 phi). The estuarine mud, both above and below the oyster beds, has a sand content of only $2-28 \%$ with mean grain sizes between 6.2 and 8.3 phi (Fig. 7).

\section{Discussion}

\subsection{Geologic control on oyster reef distribution}

Studies of environmental conditions indicate that salinity, temperature and nutrient availability influence the oyster population of Apalachicola Bay (Livingston et al., 2000). Yet the distribution of oyster reefs in the bay is not exclusively controlled by oceanographic conditions. Otherwise the reefs would be found in a more symmetrical and uniform pattern around the mouth of the river. Instead the reefs occur in isolated patches at a scale that is finer than measured variation in oceanographic and nutrient conditions (Livingston et al., 2000; Huang et al., 2002a,b). The close association between present oyster reefs and exposed Pleistocene sand in St. George Sound and Holocene sandy deltaic deposits in Apalachicola Bay indicates that substrate type has a strong control on oyster distribution (Fig. 4A, B). Both string and patch reefs have 

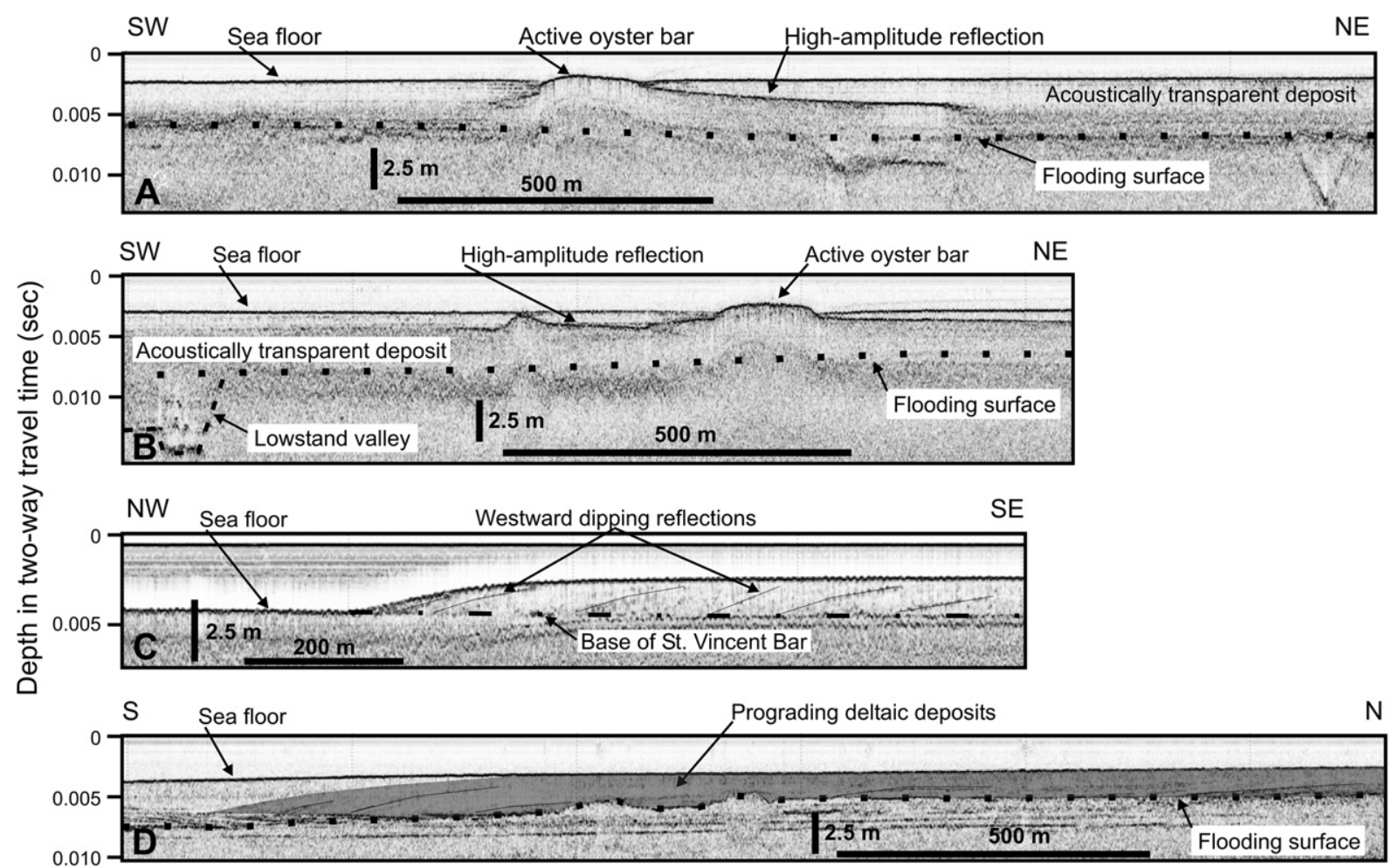

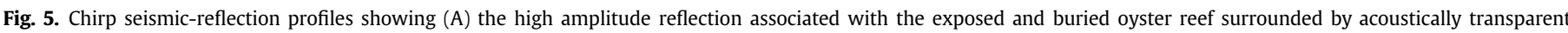

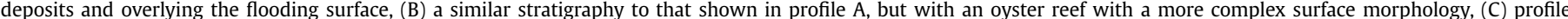

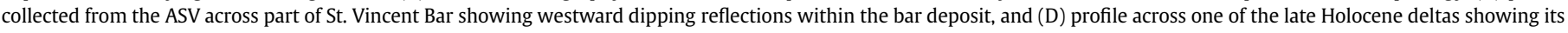
southward progradation over an irregular flooding surface. Profile locations are shown in Fig. 1.
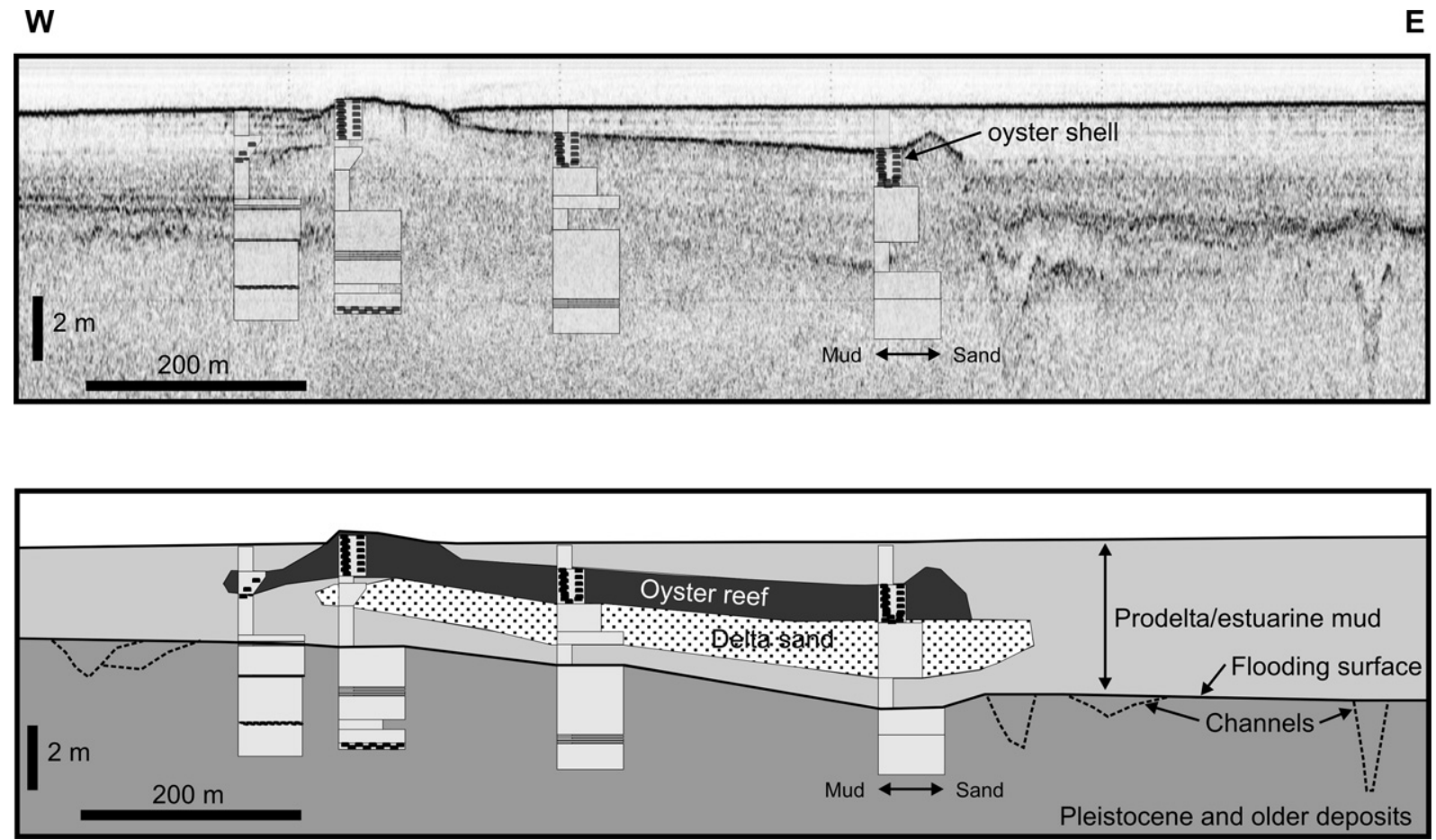

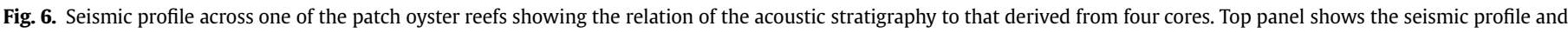
the lithologic logs for the four cores, and bottom panel shows an interpretation of the shallow stratigraphy. 


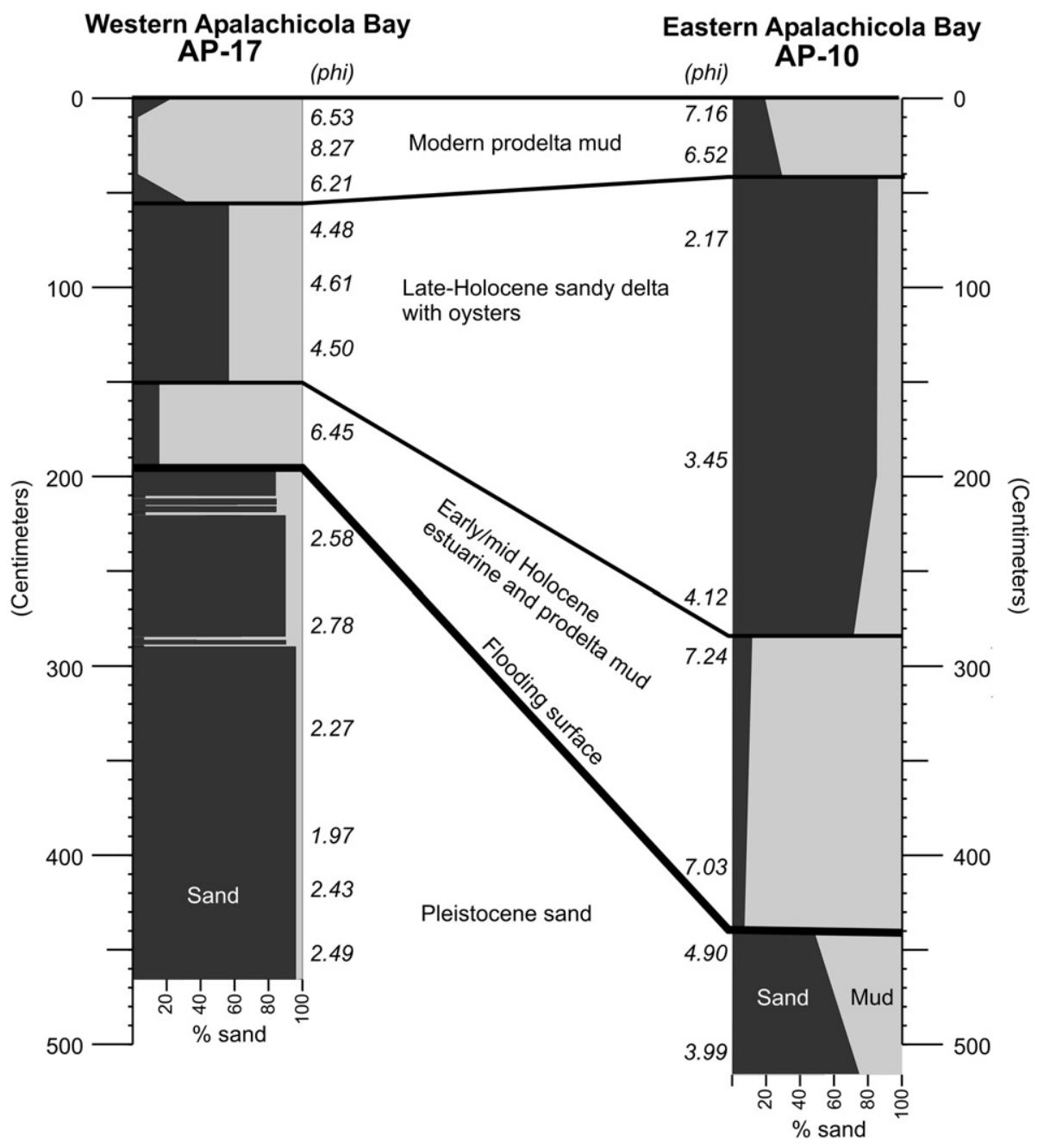

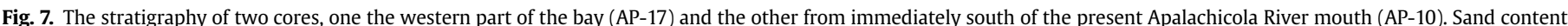

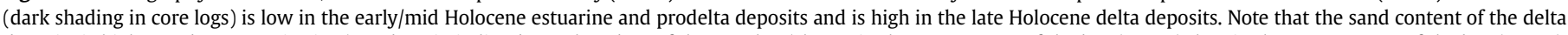

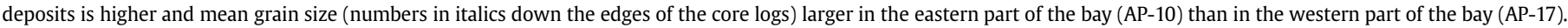
Core locations are shown in Fig. 1.

been initiated on sandy substrates. By contrast, no oyster reefs occur where fine-grained sediment was deposited during the late Holocene (Figs. 3, 4A). While substrate type contributes to oyster reef distribution, it is not the sole control. The absence of oyster reefs east of Porter's Bar and west of St. Vincent Bar (Fig. 1), both areas where the bay floor is sandy, is likely controlled by changes in salinity and nutrient availability due to increased distance from the river mouth (Fig. 3).

While the substrate type partially controls the distribution of oyster reefs in the bay, variations in the relief of the reefs varies with distance from the mouth of the Apalachicola River. The reefs in the east and west of the study area rise $1-1.5 \mathrm{~m}$ above the surrounding sea floor (Fig. 2B, D) while those located immediately south of the river mouth only rise about $0.5 \mathrm{~m}$ above the surrounding sea floor (Fig. 2C). The higher suspended sediment concentrations immediately off the river mouth may limit the growth of oysters there and also may contribute to more rapid burial of the reef margins than in other parts of the study area.

\subsection{Evolution of oyster reefs}

While warm-cool climate changes appear to have controlled oyster colonization in the Hudson River (Carbotte et al., 2004), in the Apalachicola Bay region slight changes in sea level appear to have had more influence on shifts in oyster distribution. In the northern Gulf of Mexico region, sea level was 6-7 m lower $6000 \mathrm{yr}$ BP, rose to its present elevation by $5200 \mathrm{yr} \mathrm{BP}$, and then dropped about $2.5 \mathrm{~m}$ by $4400 \mathrm{yr}$ BP before rising to slightly above its present level by $3800 \mathrm{yr}$ $\mathrm{BP}$ and oscillating around this level to the present (Balsillie and Donoghue, 2004). The oyster beds in Apalachicola Bay rest on top of late Holocene sandy delta deposits (Fig. 4) that formed in the bay between 6400 and $4400 \mathrm{yr}$ BP. Radiocarbon dates indicate that the final advance of the western delta system that underlies St. Vincent Bar occurred during the drop in sea level between 5200 and $4400 \mathrm{yr}$ $\mathrm{BP}$ (Osterman et al., 2009). At the end of this time interval sea level was about $2.5 \mathrm{~m}$ lower than present (Fig. 8A). The subsequent rise in sea level and continued fine-grained sediment input from the Apalachicola River appear to have contributed to changes in the distribution and morphology of these oyster reefs.

Evidence for a higher stand of sea level in the Apalachicola Bay region $4000 \mathrm{yr}$ BP is provided by dated material from early human settlements, which suggests that the active leading edge of the delta was well inland of its present location (Donoghue and White, 1995). Settlements in the Apalachicola River valley become progressively younger towards the south after $4000 \mathrm{yr} \mathrm{BP}$, presumably in response to the delta readvancing into the bay. A human shell midden at a site approximately $5 \mathrm{~km}$ north of the present delta shoreline shows the transition from oysters to 
W

E
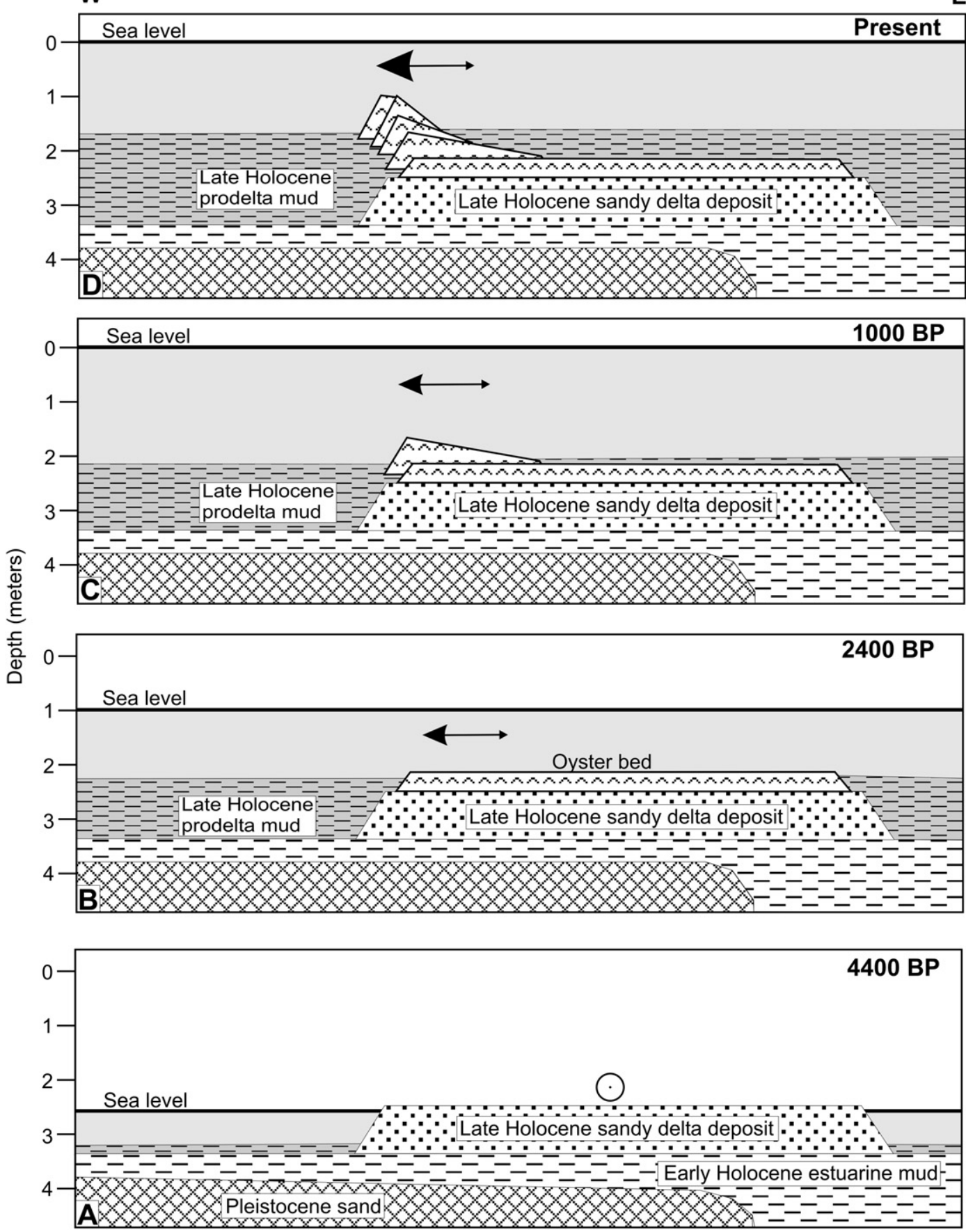

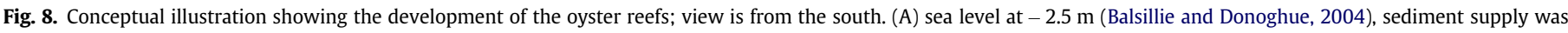

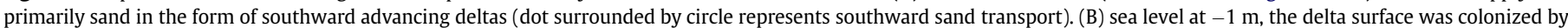

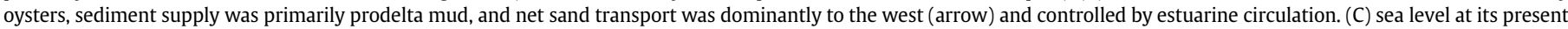

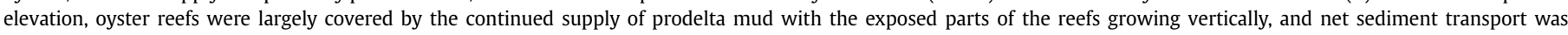
dominantly to the west (arrow). (D) oyster reefs continue to grow vertically and migrate westward as their flanks are buried by prodelta mud.

freshwater clams at $3000 \mathrm{yr}$ BP, a record of change from an estuarine to freshwater environment as the delta advanced southward past this location.

By $2400 \mathrm{yr}$ BP large parts of Apalachicola Bay appear to have been optimal for oysters. Cores show that areas where delta sands were present were extensively colonized by oysters (Figs. 6, 8B). Sea level was near its present elevation and oyster colonization may have been favored by an expansion of the barrier islands that caused the development of estuarine conditions in the bay (Osterman et al., 2009).

In the early stages of colonization, the oyster beds appear to have been broad low-relief sheets (Fig. 8B), but they have evolved to the present narrow patch and string reefs (Fig. 8C, D) in response to continued filling of the bay by prodelta mud. In addition to burial by prodelta mud, hurricanes and large storms have been shown to disperse and at least temporarily bury oyster beds with mud 
resuspended from the bay floor during storms (Edmiston et al., 2008). The present morphology of the oyster reefs suggests they counter the continued burial of their edges by prodelta mud and the continuing rise of sea level by growing vertically (Fig. 8C, D). Vertical growth is achieved by oyster larvae colonizing the shelly parts of the reef surface that remain above the mud that is accumulating on the sea floor (Lenihan, 1999). Initially oyster reefs covered large areas, and seismic profiles show that some reefs grew vertically along both edges of the original oyster bed but most only grew on the western side (Fig. 5A, B). With the vertical growth, the flow over the reefs became more restricted and the intensified currents would reduce accumulation of fines (Lenihan, 1999).

In addition to growing vertically, the internal structure of St. Vincent Bar (Fig. 5C) indicates a westward migration of this reef. The internal structure of the other reefs could not be imaged seismically, but the asymmetry of all the reefs is consistent with a net westward migration (Figs. 2B-D, 8D). The asymmetrical morphology of these reefs is similar to that of sand waves and sand ridges in tide-dominated settings where bedform asymmetry indicates net sediment transport directions (Belderson and Stride, 1969). The morphological similarity of the oyster reefs with the sand ridges suggests a net westward movement of the oyster reefs although transport does not appear to be controlled by tidal currents which are not strong enough to mobilize sediment in the bay. Easterly and westerly directed wind-generated currents, however, can exceed $30 \mathrm{~cm} / \mathrm{s}$ (Huang et al., 2002b); a speed that is sufficient to move fine sand. Although easterly and westerly directed wind-generated currents are of equal strength (Huang et al., 2002b), models show a weak westward directed residual current in the bay (Livingston et al., 2000), and the asymmetry of the oyster reefs is consistent with the westerly directed transport of sediment dominating over transport to the east.

\subsection{The fate of oyster reefs}

Oysters are a major fishery in Apalachicola Bay but the establishment of the present reefs is fairly recent in the bay's history, and their extent has varied through time. Presently oyster reefs are much less extensive than $1500-2400 \mathrm{yr}$ BP. This decrease is due to the interplay of processes acting within and external to the bay. External to the bay, recent decreases in freshwater and sediment supply to the bay heave been attributed to the construction of dams within the bay's watershed (Livingston et al., 2000). Recent changes in organic matter in bay sediments suggest an increased marine influence in the bay due to a combination of rising sea level and decreased river input (Surratt et al., 2008). Predictions of continued sea level rise (IPCC, 2007) and increases in storm intensity (Emanuel, 2005) will both increase the marine influence on the bay in the future. Within the bay, hydrographic conditions and the geomorphology of the bay result in much of the nutrients and suspended sediment supplied by the Apalachicola River being trapped in the bay (Fig. 1). During the late Holocene, the oyster reefs have responded to this effective trapping of sediment by becoming narrower and growing vertically to keep ahead of sedimentation and the rise in sea level. Due to the continued input of fine-grained sediment to the bay, available habitat for oyster larvae growth is now reduced to areas where oyster shell is exposed on the sea floor (Fig. 8). Storms further reduce the extent of the reefs by redistributing coarse material from the reefs into the deeper parts of the bay where it is buried by mud (Edmiston et al., 2008). The combination of predicted increased storm intensity (Emanuel, 2005) and continued, albeit reduced input of fine-grained sediment to the bay will continue to reduce the size of oyster reefs, and likely will bury them if oyster growth cannot keep pace with sedimentation in this changing estuarine environment.

\section{Conclusions}

The distribution of oyster reefs in the Apalachicola Bay estuary is influenced by a variety of conditions, and here we demonstrate the contribution that the shallow stratigraphy has on their distribution. Oyster reefs were all initiated on Pleistocene sandy surfaces in St. George Sound or late Holocene sands associated with deltas that advanced into the bay at this time. Results from cores and seismic profiles suggest that initially oyster reefs were more extensive and have decreased as their edges have been buried by the continued input of fine-grained sediment to the estuary by the Apalachicola River. The morphology of the oyster reefs indicates that they have responded to sediment accumulation by growing vertically. The asymmetry of the oyster reefs and their internal structure indicate that they have migrated towards the west suggesting a net westward transport of sediment in the bay. The geological influence on the oyster reefs and future changes in the distribution and extent of oyster reefs will assist in managing this oyster fishery.

\section{Acknowledgments}

Funding for this research was provided by both the NOAA Coastal Services Center. We acknowledge the assistance of E. Bergeron, W. Danforth, J. Denny, B. Irwin, T. O'Brien, and C. Worley of the USGS for their assistance in collecting and processing the data. Additional support for field operations was provided by Apalachicola Bay National Estuarine Research Reserve staff members J. Wanat, L. Levi, M. Lamb, and S. Fahrny. We appreciate the constructive reviews by P. Valentine and W. Winters. Any use of trade names or company names is for descriptive purposes only and does not imply endorsement by the U.S. Government.

\section{References}

Balsillie, J.H., Donoghue, J.F., 2004. High resolution sea-level history for the Gulf of Mexico since the last glacial maximum, Florida Geological Survey Report of Investigations No. 103, 66 pp.

Banister, S.D., 2008. Geomorphic change since the early Holocene in Apalachicola Bay, Florida. MS Thesis, Florida State Univ. Tallahassee, FL. 101 pp.

Belderson, R.H., Stride, A.H., 1969. Tidal currents and sand wave profiles in the north-eastern Irish Sea. Nature 222, 74-75.

Bergeron, E., Worley, C.R., O'Brien, T.F., 2007. Progress in the development of shallow-water mapping systems: using an autonomous surface vehicle for shallow-water geophysical studies. Sea Technology 48 (no. 6), 10-15

Carbotte, S.M., Bell, R.E., Ryan, W.B.F., McHugh, C., Slagle, A., Nitsche, F., Rubenstone, J., 2004. Environmental change and oyster colonization within the Hudson River estuary linked to Holocene climate. Geo-Marine Letters 24 212-224.

DeAlteris, J.T., 1988. The geomorphic development of Wreck Shoal, a subtidal oyster reef on the James River. Estuaries 11, 240-249.

Donoghue, J.F., 1992. Late quaternary coastal and inner shelf stratigraphy, Apalachicola delta region, Florida. Sedimentary Geology 80, 293-304.

Donoghue, J.F., 1993. Late Wisconsinan and Holocene depositional history, northeastern Gulf of Mexico. Marine Geology 112, 185-205.

Donoghue, J.F., White, N.M., 1995. Late Holocene sea-level change and delta migration, Apalachicola River region, northwest Florida, U.S.A. Journal of Coastal Research 11, 651-663.

Edmiston, H.L., Fahrny, S.A., Lamb, M.S., Levi, L.K., Wanat, J.M., Avant, J.S., Wren, K., Selly, N.C., 2008. Tropical storm and hurricane impacts on a Gulf coast estuary: Apalachicola Bay, Florida. Journal of Coastal Research 55, 38-49.

Emanuel, K.A., 2005. Increasing destructiveness of tropical cyclones over the past 30 years. Nature 436, 686-688.

Fielder, B.R., Dellapenna, T.M., Savarese, M., 2006. Anthropogenic and natural influences on present-day sediment deposition and oyster reef distribution and restoration for the Naples Bay estuarine complex. Eos Transactions AGU 87 (36) Ocean Science Meeting Supplement Abstract OS46C-06.

Huang, W., Sun, H., Nnaji, S., Jones, W.K., 2002a. Tidal hydrodynamics in a multipleinlet estuary: Apalachicola Bay, Florida. Journal of Coastal Research 18, 674-684.

Huang, W., Jones, W.K., Wu, T.S., 2002b. Modelling wind effects on subtidal salinity in Apalachicola Bay, Florida. Estuarine, Coastal and Shelf Science 55, 33-46.

IPCC (Intergovernmental Panel on Climate Change), 2007. Climate change 2007: the physical science basis. In: Solomon, S., Qin, D., Manning, M., Chen, Z., Marquis, M., Averyt, K.B., Tignor, M., Miller, H.L. (Eds.), Contribution of Working 
Group I to the Fourth Assessment Report of the Intergovernmental Panel on Climate Change. Cambridge University Press, Cambridge, UK and New York, p. 996.

Isphording, W.C., 1986. Apalachicola Bay: dynamic sedimentation in a Gulf coast estuary. Gulf Coast Association of Geological Societies Transactions 36, 471-488.

Kennedy, V.S., Newell, R.I., Eble, A.F., 1996. The eastern oyster: Crassostrea virginica. Maryland Sea Grant Book, College Park, MD, pp. 371-421.

Kofoed, J.W., Gorsline, D.S., 1963. Sedimentary environments in Apalachicola Bay and vicinity, Florida. Journal of Sedimentary Petrology 33, 205-223.

Leitman, H.M., Sohm, J.E., Franklin, M.A., 1983. Wetland hydrology and tree distribution of the Apalachicola River flood plain, Florida. U.S, Geological Survey Water-Supply Paper 2196-A, 52 pp.

Lenihan, H.S., 1999. Physical-biological coupling on oyster reefs: how habitat structure influences individual performance. Ecological Monographs 69, $251-275$.

Livingston, R.J., Lewis, F.G., Woodsum, G.C., Niu, X.-F, Galperin, B., Huang, W. Christensen, J.D., Nonaco, M.E., Battista, T.A., Klein, C.J., Howell, R.L., Ray, G.L. 2000. Modelling oyster population response to variation in freshwater input. Estuarine, Coastal and Shelf Science 50, 655-672.

McKeown, H.A., Bart, P.J., Anderson, J.B., 2004. High-resolution stratigraphy of a sandy, ramp-type margin - Apalachicola, Florida, U.S.A. In: Anderson, J.B., Fillon, R.H. (Eds.), Late Quaternary stratigraphic evolution of the northern Gulf of Mexico. SEPM, Tulsa, OK, pp. 25-41. Special Publication No. 79.

Niu, X.-F., Edmiston, H.L., Bailey, G.O., 1998. Time series models for salinity and other environmental factors in the Apalachicola estuarine system. Estuarine, Coastal and Shelf Science 46, 549-563.
Osterman, L.E., Twichell, D.C., Poore, R.Z., 2009. Holocene evolution of Apalachicola Bay, Florida. Geo-Marine Letters 29, 395-404.

Schnable, J.E., Goodell, H.G., 1968. Pleistocene-Recent stratigraphy, evolution, and development of the Apalachicola coast, Florida. Geological Society of America, Boulder, CO. Special Paper No. 112pp. 1-65.

Schulte, D.M., Burke, R.P., Lipcius, R.N., 2009. Unprecedented restoration of a native oyster metapopulation. Science 325, 1124-1128.

Smith, G.F., Roach, E.B., Bruce, D.G., 2003. The location, composition, and origin of oyster bars in mesohaline Chesapeake Bay. Estuarine, Coastal and Shelf Science 56, 391-409.

Stenzel, H.B., 1971. Oysters, pp. N953-N1196. In: Moore, R.C. (Ed.), Treatise on invertebrate paleontology, Part N Bivalvia, Vol. 3. Geological Society of America, Boulder, CO.

Surratt, D., Cherrier, J., Robinson, L., Cable, J., 2008. Chronology of sediment nutrient geochemistry in Apalachicola Bay, Florida (U.S.A.). Journal of Coastal Research 24, 660-671.

Twichell, D., Andrews, B., Edmiston, L., Stevenson, B., 2007. Geophysical mapping of oyster habitats in a shallow estuary: Apalachicola Bay, Florida. USGS. http:// woodshole.er.usgs.gov/pubs/of2006-1381/ Open-File Report 2006-1381, online.

Twichell, D.C., Pendleton, E.A., Poore, R.Z., Osterman, L.E., Kelso, K., 2009. Vibracore, radiocarbon, microfossil, and grain-size data from Apalachicola Bay, Florida. USGS. http://pubs.usgs.gov/of/2009/1031 Open-File Report 2009-1031, online.

Whitfield, W.K. Beaumariage, D.S. 1977. Shellfish management in Apalachicola Bay: past, present and future. In: Livingston, R.J., Joyce, E.A. (Eds.), Proceedings of the Conference on the Apalachicola drainage system, Vol. 26. Florida Department of Natural Resources Marine Research Publications, pp. 130-140. 